\title{
Reactie
}

\section{Handhaving van de patriarchale orde of ingaan op de dynamiek van de Geest?}

H. Jansen

In een recent interview over zijn secularisatietheorie herinnert de Canadese filosoof Charles Taylor aan het verdwijnen van het besef van een kosmische orde als belangrijk aspect van secularisatie, naast de 'onttovering' van de werkelijkheid en processen van neergang van het geloof. ${ }^{1}$ De teloorgang van het beleven van de werkelijkheid als stabiel geordend in vaste verbanden kan helpen om te begrijpen waarom we in de discussie over de vrouw in het ambt langs elkaar heen praten. De Gereformeerde Bond wil graag de secularisatie tegenhouden en vindt het daarom belangrijk om de orde te handhaven, de 'scheppingsorde' die de eeuwen door verstaan is als een patriarchale orde. Voor mij en velen met mij is dat een vergeefs achterhoedegevecht.

Hoek en Te Velde vinden dat de brochures van de Bond bereidheid tonen om water in de wijn te doen wat betreft de theologie van de regeermacht van de man. Zij komen op voor veel ruimte voor vrouwen in de kerk, althans zolang het maar niet in het ambt en het kerkbestuur of op de preekstoel is. Maar het hele artikel spreekt de taal van een orde die mensen op hun plaats zet, die identiteit verschaft en die eigenheden handhaaft. Zij willen die orde niet hiërarchisch noemen. Het zijn plekken om te dienen. Maar het moeten wel aparte plekken blijven. Er mag vooral geen menging van identiteiten plaatsvinden. En de vrouw moet zwijgen in de kerk. God wil het.

Hoek en Te Velde geven opvallend grif toe dat er langs wetenschappelijke weg niet veel van zo'n scheppingsorde te ontdekken valt. Enige vorm van plausibele wetenschappelijke consensus over verschillen tussen mannelijke en vrouwelijke identiteit zien zij niet aan de horizon verschijnen. Ze vinden dat die er voor het begrip van het zwijggebod voor vrouwen ook eigenlijk niet toe

1 'These are two understandings (..) ourselves in terms of magical forces and cosmic order which I think have totally disappeared in what I call the "immanent frame" we now live in, where the natural world is understood through today's best natural science, and the human world is understood as created by human beings.', In Michiel Meijer en Herbert De Vriese (red.), The Philosophy of reenchantment, 2021, p. 18. 
doet. We moeten het er gewoon mee doen dat God het voorgaan van vrouwen verboden heeft. Ook als het Hem belieft zijn motieven (de 'ratio') verborgen te houden.

Met zo'n decisionistische benadering wordt de theologische verantwoording van het vrouwenverbod nog fundamentalistischer dan de verantwoording die nog wel een beroep deed op een regeermacht die ook uit natuur en geschiedenis afleesbaar zou zijn. ${ }^{2}$ Ook de GB ontloopt dus niet het voortschrijden van de secularisatie. $\mathrm{Nu}$ is de goddelijke orde alleen nog uit de Schrift te halen.

Geen wonder. Er is in werkelijkheid geen zesduizend jaar oude scheppingsorde. Ook geen oudere. We leven in een dynamische werkelijkheid van een miljoenen jaren voortschrijdende evolutie en van historische en sociale processen met voortdurende veranderingen en verschuivingen in patronen van interactie en communicatie. We hebben biologisch daarbij wel het dna met zijn informatie als sturende factor. Ik stelde voor om daarvoor de Schepper te prijzen, maar niet om daarbij de oude scheppingsordeningentheologie te handhaven. Het was een aanmoediging om die los te laten.

En ik bracht Miroslav Volf in als voorbeeld van theologie die in de taal van dynamiek en interactie schrijft over het werk van de Geest en hoe daarin identiteiten opbloeien en worden vernieuwd. Hoek en Te Velde hebben er opvallend weinig antenne voor. Ze blijven steken in ordinantiedenken over vaste posities en eigenheden. Ze zijn zelfs bereid om Efeziërs 5 naar hun hand te zetten. Ze betwisten zowel dat er in vers 21 sprake is van 'wederzijdse onderwerping' van mannen en vrouwen, als dat dit een beslissend voorteken zou zijn voor het vervolg over de man-vrouwrelatie. ${ }^{3}$ Er staat volgens hen dat alleen op voorwaarde van handhaving van ieders eigenheid er sprake kan zijn van gelijke opdracht tot liefdedienst. Terwijl - zo was mijn betoog - het net andersom is. Alleen op voorwaarde van de wederzijdse dienstbaarheid op voet van gelijkheid (of gelijkwaardigheid, van semantische twisten wil ik ook wel af) en in de gemeenschap van de liefdevolle tedere omgang met elkaar waarin man en vrouw zich aan elkaar schenken, bloeit ieders eigenheid op. En de bestaande maatschappelijke orde wordt niet gehandhaafd, maar aan

2 Decisionisme: 'De opvatting dat de beslissing voor een prescriptieve norm of een handelwijze (..) een voldoende grond kan zijn voor de legitimiteit van deze norm of handelwijze', wikipedia ('decisionisme').

3 'Alleen is de stelling dat Efeze 5 draait om wederzijdse onderschikking aanvechtbaar, en moet er ten minste ook recht gedaan worden aan de 'onverwisselbare eigenheid' die blijkens dit hoofdstuk aan man en vrouw toekomt.' Maar in Ef. 5: 21 staat toch echt 'hupotassomenoi allelois'. 
een revolutionair vernieuwende dynamiek onderworpen. Op een vergelijkbare manier proberen zij het betoog over 1 Korintiërs 11 onschadelijk te maken. Hun voornaamste zorg is of de afzonderlijke genderidentiteiten niet verdwijnen, terwijl de vraag was of gezien werd dat Paulus bezig was om het 'hoogteverschil' binnen de patriarchale orde maximaal te nivelleren.

Achter de zwijgteksten zit mogelijk een missionair motief, maar heel zeker een patriarchale orde. Hoek en Te Velde willen vanwege dat laatste wel enige 'spanning' toegeven met andere teksten. Maar inconsistentie mag het niet heten. Het is tenslotte de Heilige Schrift waarvan ook het culturele kleed sacrosanct is. Maar is de Schrift hier dan niet net zo inconsistent is als wanneer - op een ander vlak - twee ezels in het ene intochtsverhaal staan tegenover maar één in het andere? En ondertussen is die patriarchale orde geen zesduizend jaar oude scheppingsorde, maar een culturele uitvinding van de mensheid uit de tijd van de landbouwrevolutie. Oudere egalitaire samenlevingsvormen van jager-verzamelaars werden vervangen door vormen gebaseerd op hiërarchie en het primaat van de man. ${ }^{4}$ Het is dezelfde orde die ook slavernij met zich meebracht en dat in feite doet tot op vandaag.

Waarom zoveel krampachtigheid? In het nieuwe seculum van processen, dynamieken en patronen valt prima te leven. We redden het staatkundig bijvoorbeeld al meer dan 170 jaar (min 5) met een democratische rechtstaat met flexibele grondwet die de soevereine vorst-bij-de-gratie-Gods van fundament en garant van de van God gegeven orde veranderd heeft tot ornament en symbool. ${ }^{5}$ Vrouwen, slaven en kinderen zijn er sindsdien enorm op vooruit gegaan, helaas meer ondanks dan dankzij reformatorische theologie. ${ }^{6}$

En er valt in dat seculum ook prima te geloven. Omdat ook daarin het historische kruis staat, de impuls van het evangelie er zijn werking heeft en de Geest er van haar gaven en krachten, haar 'charisma's' en dynameis, blijk geeft. Het kan, als het maar niet hoeft met God als de eeuwige Patriarch van wie de Zoon zelfs in zijn opstanding nog Man is in plaats van 'de nieuwe

4 Carel van Schaik, Kai Michel, Het oerboek van de mens. De evolutie en de Bijbel, 2017; K. Armstrong, De grote transformatie, Amsterdam 2006.

5 Heel instructief over de ingrijpende verandering van 1848 is de biografie van R. Aerts, Thorbecke wil het, 2020.

6 'Goede theologie heeft steeds de culturele vanzelfsprekendheden ter discussie gesteld': van deze goede theologie valt er in de $19^{\text {de }}$ eeuw helaas weinig te bespeuren. Het was dezelfde liberaal Thorbecke die met zijn tweede kabinet de slavernij afschafte en die vlak voor zijn dood tekende voor het toelaten van Aletta Jacobs tot de universiteit, en het was zijn volgeling Samuël van Houten die met het beroemde 'kinderwetje' kwam dat kinderarbeid verbood. In de orthodoxe theologie van die tijd ben ik deze thema's niet tegen gekomen. 
Mens'. Als het in elk geval ook mag met andere beelden en woorden en met schrijfwijzen waarin 'Hij' met eerbiedskapitaal niet exclusief verplichtend is. En in dat seculum heeft de kerk haar missie. Vooral als er in de wereld nog zo veel misgaat met het 'aandoen van de nieuwe mens' en het afleggen van de oude Adam en Eva. Er is weinig culturele analyse voor nodig om te zien hoezeer onze tijd vraagt om 'feministisch met de feministen' te worden om althans enigen te winnen. En dan is het natuurlijk contraproductief om de kerk met de 'cultuuropdracht' te belasten om een tegendraadse antieke man/ vrouworde aan die werkelijkheid op te leggen.

Hoek en Te Velde krijgen het niet goed over de lippen dat het evangelie in essentie een antipatriarchale injectie in de geschiedenis is. Vanuit de botsing tussen het denken in termen van vaste ordeningen dan wel dynamische processen en patronen valt te verklaren waarom discussie over de vrouw in het ambt zo vaak tot een herhaling van zetten leidt. Er staat een bredere werkelijkheidsbeleving op het spel.

Maar in deze kwestie gaat het ook concreet om de toegang tot betaalde posities in de kerk gekoppeld aan een goede traktementsregeling. Bij andere organisaties heet het weigeren van zo'n toegang louter op grond van geslacht discriminatie. Daar is dat grondwettelijk strafbaar. Hoek en Te Velde betreuren mijn herinnering aan de scherpe taal van de WCRC en ze wensen meer gesprek, respect, gebed en ruimte voor bestaande vragen (welke?). Maar hebben zij gevoel voor het feit dat zij als mannen deze mannelijke voorrechten aan het verdedigen zijn? Over het moreel en theologisch gerechtigd zijn daartoe hebben wij een grondig meningsverschil. Met alle waardering voor het feit dat dit op tafel gelegd mag worden en met alle respect, we komen er niet uit door zoete broodjes te bakken. Dit vraagt degelijke argumentatie en een gevoel van urgentie.

'Kom hoger op, vrienden!' 